\title{
Uridine adenosine tetraphosphate induces contraction and relaxation in rat aorta
}

\author{
A. Elizabeth Linder, Michelle Tumbri, Felipe F.P. Linder, R. Clinton Webb, Romulo Leite* \\ Department of Physiology, Medical College of Georgia, Augusta, GA 30912-3000, USA
}

\section{A R T I C L E I N F O}

Article history:

Received 31 December 2007

Accepted 20 March 2008

\section{Keywords:}

Uridine adenosine tetraphosphate

Rat aorta

Contraction

Relaxation

Purinergic receptors

\begin{abstract}
A B S T R A C T
Uridine adenosine tetraphosphate $\left(\mathrm{Up}_{4} \mathrm{~A}\right)$ has been recently reported as an endothelium-derived vasoconstrictor and plasma levels of this dinucleotide are increased in juvenile hypertensive subjects. This study aimed to evaluate the vascular actions of $U_{4} A$, typify the putative purinergic receptors that might mediate these effects and characterize the intracellular signaling pathways that may govern $U_{4} A$ responses. $\mathrm{Up}_{4} \mathrm{~A}$ induced a modest endothelium-dependent relaxation of rat aortic rings contracted with phenylephrine. From baseline, $\mathrm{Up}_{4} \mathrm{~A}$ induced concentration-dependent contractions that were significantly potentiated by endothelium removal or nitric oxide synthase inhibition. The contractile response induced by $\mathrm{Up}_{4} \mathrm{~A}$ was not tachyphylactic and was significantly reduced in the presence of P1 or P2X receptor antagonists, L-type Ca ${ }^{2+}$ channel blocker and Rho-kinase inhibitor. $\mathrm{Up}_{4} \mathrm{~A}$-induced contraction apparently involves superoxide anion formation since it was significantly reduced by treatment with apocynin or tempol. This study presents the unique findings that the endogenous compound $\mathrm{Up}_{4} \mathrm{~A}$ is able to induce relaxation in addition to contraction of rat aorta. $\mathrm{Up}_{4} \mathrm{~A}$-induced contraction is modulated by nitric oxide production, mediated by $\mathrm{P} 1$ and $\mathrm{P} 2 \mathrm{X}$ receptor activation, and involves L-type $\mathrm{Ca}^{2+}$ channels, Rho-kinase pathway and superoxide formation.
\end{abstract}

Published by Elsevier Inc.

\section{Introduction}

Extracellular nucleotides contribute to the local regulation of vascular tone (Buvinic et al., 2006; Inscho and Cook, 2002; Ralevic and Burnstock, 1991). Uridine adenosine tetraphosphate $\left(\mathrm{Up}_{4} \mathrm{~A}\right)$ has been recently described as a novel non-peptidic endothelium-derived vasoconstrictive factor (Jankowski et al., 2005). This factor, isolated from human endothelial cells, increases mean arterial pressure and perfusion pressure in isolated kidneys of rats, suggesting a role for $\mathrm{Up}_{4} \mathrm{~A}$ in the regulation of vascular tone.

Purinoceptors have been classified into two subtypes: P1 and P2 receptors, based on their pharmacological properties and molecular clonings (Dalziel and Westfall, 1994; Knight and Burnstock, 2001). Adenosine and its phosphates, ATP and ADP, have been identified as the endogenous ligands for P1 and P2 receptors, respectively (Fredholm et al., 1994; Malec, 1996). Four subtypes of P1 receptors, all metabotropic, have been cloned, namely A1, A2A, A2B and A3 (Ralevic and Burnstock, 1998). The P2 receptors for nucleotides exist in two major families: metabotropic (P2Y receptors) and ionotropic (P2X receptors). There are at least 8 cloned $\mathrm{P} 2 \mathrm{Y}$ and 7 cloned $\mathrm{P} 2 \mathrm{X}$ receptors (Boarder and Hourani, 1998; Burnstock, 2004; Communi et al., 2000; North, 2002). Most of these receptors are capable of mediating

\footnotetext{
* Corresponding author. Medical College of Georgia, Department of Physiology, 1120 Fifteenth Street (CA-3135), Augusta, GA, 30912-3000, USA. Tel.: +1 7067217814 ; fax: +1 7067217299 .

E-mail address: rleite@mcg.edu (R. Leite).
}

responses to several nucleotides, resulting in multiple receptors having overlapping ligand preferences (Ralevic and Burnstock, 1998).

In isolated perfused rat kidney, $\mathrm{Up}_{4} \mathrm{~A}$ was found to induce vasoconstriction through $\mathrm{P} 2 \mathrm{X} 1, \mathrm{P} 2 \mathrm{Y} 2$ and $\mathrm{P} 2 \mathrm{Y} 4$ receptor activation (Jankowski et al., 2005). The vasodilatory effect of this compound has not been tested.

Because $U p_{4} A$ is secreted by human endothelial cells and is present in effective concentrations in human plasma, a role for $\mathrm{Up}_{4} \mathrm{~A}$ in the regulation of vascular tone and in cardiovascular disease seems to be likely. More recently it has been reported that plasma $\mathrm{Up}_{4} \mathrm{~A}$ levels are increased in human juvenile hypertension and has a significant proliferative effect on human smooth muscle cells (Jankowski et al., 2007).

The present experiments were carried out in order to characterize the responses induced by $U \mathrm{p}_{4} \mathrm{~A}$ in rat aorta. We hypothesized that $\mathrm{Up}_{4} \mathrm{~A}$ induces contraction of rat aortic smooth muscle. In an attempt to characterize $\mathrm{Up}_{4} \mathrm{~A}$-induced contraction, $\mathrm{P} 1$ and $\mathrm{P} 2$ receptor antagonists, inhibitors of $\mathrm{Ca}^{2+}$ channels and Rho-kinase were tested. The involvement of the endothelium, nitric oxide and superoxide anion was also evaluated.

\section{Materials and methods}

\subsection{Animals}

Male Sprague Dawley rats (250-300 g, Harlan Laboratories, Indianapolis, IN) were maintained on a $12 \mathrm{~h}$ light/dark cycle with access to water and standard rat chow ad libitum. On the day of an experiment, rats were anesthetized with $\mathrm{CO}_{2}$ and the thoracic aorta 
was excised. All experiments were conducted in accordance with the Medical College of Georgia's Animal Use for Research and Education Committee.

\subsection{In vitro measurement of isometric force generation in rat aortic rings}

After removal of fat and connective tissue, aortic rings ( $3 \mathrm{~mm}$ long) were mounted in an organ chamber (Danish MyoTechnology, Aarhus, Denmark) for isometric tension recordings (ADinstruments, Castle Hill, Australia) and bathed in physiological salt solution (PSS) of the following composition: $130.0 \mathrm{mM} \mathrm{NaCl}, 4.7 \mathrm{mM} \mathrm{KCl}, 1.2 \mathrm{mM} \mathrm{KH_{2 }} \mathrm{PO}_{4}, 1.2 \mathrm{mM}$ $\mathrm{MgSO}_{4}, 1.6 \mathrm{mM} \mathrm{CaCl}_{2}, 14.9 \mathrm{mM} \mathrm{NaHCO}, 0.03 \mathrm{mM}$ EDTA, and $5.5 \mathrm{mM}$ glucose, which was maintained at $37{ }^{\circ} \mathrm{C}$ and bubbled with $95 \% \mathrm{O}_{2}$ and $5 \%$ $\mathrm{CO}_{2}$. The aorta segments were stretched at a tension of $30 \mathrm{mN}$ with periodic washes every $15 \mathrm{~min}$. After a 1-hour equilibration period, vessels were contracted with phenylephrine $\left(10^{-7} \mathrm{M}\right)$ and subsequently challenged with acetylcholine $\left(10^{-5} \mathrm{M}\right)$ to test tissue viability and integrity of the endothelium. Aortic rings that relaxed at least $70 \%$ of contraction induced by phenylephrine were used as retaining functional endothelium $[\mathrm{E}(+)]$. Endothelium denudation $[\mathrm{E}(-)]$ was mechanically induced by gently rubbing the intimal surface of the aortic rings with a stainless steel wire. The absence of functional endothelium was confirmed by the complete lack of relaxation to acetylcholine.

\subsection{Experimental protocols}

To investigate the ability of $\mathrm{Up}_{4} \mathrm{~A}$ to induce contraction of rat aortic rings, cumulative concentration-effect curves to $\mathrm{Up}_{4} \mathrm{~A}\left(10^{-9}\right.$ to $\left.3 \times 10^{-5} \mathrm{M}\right)$ were constructed in endothelium-intact $[\mathrm{E}(+)]$ and endothelium-denuded $[\mathrm{E}(-)]$ aortic rings.

To test whether $\mathrm{Up}_{4} \mathrm{~A}$ was able to induce relaxation, $\mathrm{E}(+)$ and $\mathrm{E}(-)$ aortic rings were stimulated with phenylephrine $\left(10^{-7} \mathrm{M}\right)$ until the plateau of the contraction was obtained followed by a cumulative concentration-effect curve to $\mathrm{Up}_{4} \mathrm{~A}\left(10^{-9}\right.$ to $\left.10^{-5} \mathrm{M}\right)$.

To evaluate the contribution of nitric oxide to $\mathrm{Up}_{4} \mathrm{~A}$-induced contraction, concentration-effect curves to $\mathrm{Up}_{4} \mathrm{~A}$ were constructed in $\mathrm{E}(+)$ and $\mathrm{E}(-)$ aortic rings in the presence and absence of the nitric oxide synthase inhibitor L-NNA $\left(10^{-4} \mathrm{M}\right)$.

To assess whether $\mathrm{Up}_{4} \mathrm{~A}$-induced contraction is reversible and induces desensitization or tachyphylaxis, two consecutive cumulative concentration-effect curves to $\mathrm{Up}_{4} \mathrm{~A}\left(10^{-9}\right.$ to $\left.3 \times 10^{-5} \mathrm{M}\right)$ were constructed in aortic rings $\mathrm{E}(-)$ and $\mathrm{E}(+)$ in the presence of $\mathrm{L}-\mathrm{NNA}\left(10^{-4} \mathrm{M}\right)$. For that, after the maximum response for the last concentration was achieved in the first curve, the rings were washed several times with PSS or PSS + L-NNA for approximately 60 min until the tension returned to baseline. Subsequently, the second curve to $U_{4} A$ was then constructed.

To determine which receptors mediate the contraction induced by $\mathrm{Up}_{4} \mathrm{~A}$, concentration-effect curves to $\mathrm{Up}_{4} \mathrm{~A}$ were constructed in the presence of the P1 purinoceptor antagonist 8-PST $\left(10^{-4} \mathrm{M}\right)$; and the P2X1/P2X3 receptor antagonist NF279 $\left(10^{-4} \mathrm{M}\right)$.

To investigate the involvement of L-type $\mathrm{Ca}^{2+}$ channels in the $\mathrm{Up}_{4} \mathrm{~A}$-induced contraction of rat aortic rings, concentration-effect curves to $\mathrm{Up}_{4} \mathrm{~A}$ in $\mathrm{E}(-)$ aortic rings were evaluated in the presence of the L-type $\mathrm{Ca}^{2+}$ channel blocker nifedipine $\left(10^{-5} \mathrm{M}\right)$.

To examine the contribution of RhoA/Rho-kinase pathway to $\mathrm{Up}_{4} \mathrm{~A}-$ induced contractions, concentration-effect curves to $\mathrm{Up}_{4} \mathrm{~A}$ in $\mathrm{E}(-)$ aortic rings were evaluated in the presence of the Rho-kinase inhibitor Y-27632 $\left(10^{-7} \mathrm{M}\right)$.

To study the role of superoxide anion in the $\mathrm{Up}_{4} \mathrm{~A}$-induced contraction, $\mathrm{E}(-)$ aortic rings were contracted with $\mathrm{Up}_{4} \mathrm{~A}\left(10^{-6} \mathrm{M}\right)$ and a concentration-effect curve (3-12 $\mathrm{mM}$ ) to the superoxide anion scavenger (tempol) was performed. To confirm the involvement of superoxide anion in the $\mathrm{Up}_{4} \mathrm{~A}$-induced contraction of rat aortic ring, a concentration-effect curve to $\mathrm{Up}_{4} \mathrm{~A}$ was performed in the presence and in the absence of the NADPH oxidase inhibitor apocynin $\left(10^{-4} \mathrm{M}\right)$.
All inhibitors were added to the organ chambers $30 \mathrm{~min}$ before the start of the concentration-effect curves to $\mathrm{Up}_{4} \mathrm{~A}$, and were maintained in the organ chamber until the end of the experiment.

\subsection{Drugs}

Phenylephine hydrochloride [(R)-(-)-1-(3-hydroxyphenyl)-2methylaminoethanol hydrochloride], acetylcholine chloride, 8-( $p$ sulphophenyl)-theophylline (8-PST), 4'-hydroxy-3'-methoxyacetophenone (apocynin), 4-hydroxy-2,2,6,6-tetramethylpiperidinyloxy (tempol), 1,4-dihydro-2,6-dimethyl-4-(2-nitrophenyl)-3,5-pyridinedicarboxylic acid dimethyl ester (nifedipine) were purchased from Sigma-Aldrich, St Louis-MO, USA. The compounds [(R)-(+)-trans- $N-(4-$ pyridyl)-4-(1-aminoethyl)-cyclohexanecarboxamide.2HCl] (Y-27632), $N^{\mathrm{G}}$-nitro-${ }_{\mathrm{L}}$-arginine (L-NNA), [8,8'-(carbonylbis(imino-4, 1-phenylenecarbonylimino-4,1-phenylenecarbonylimino)) bis(1,3,5-naphthalenetrisul fonic acid)] (NF279) were acquired from Calbiochem (San Diego, California, USA). Uridine adenosine tetraphosphate $\left(\mathrm{Up}_{4} \mathrm{~A}\right)$ was purchased from Biolog - Life Science Institute (Bremen, Germany) and dimethyl sulfoxide (DMSO) from Fisher Scientific (Fair Lawn, NJ, USA). Stock solutions were prepared using sterile HPLC grade water with the exception of apocynin and nifedipine that were prepared using DMSO.

\subsection{Data analysis}

Statistical analysis was performed using one-way ANOVA followed by the Student-Newman-Keuls post hoc test for multiple comparisons. A value of $P<0.05$ was considered statistically significant. The points represent the mean \pm standard error of the mean (SEM) of the contraction in $\mathrm{mN}$ or as \% of relaxation of agonist-induced force generation.
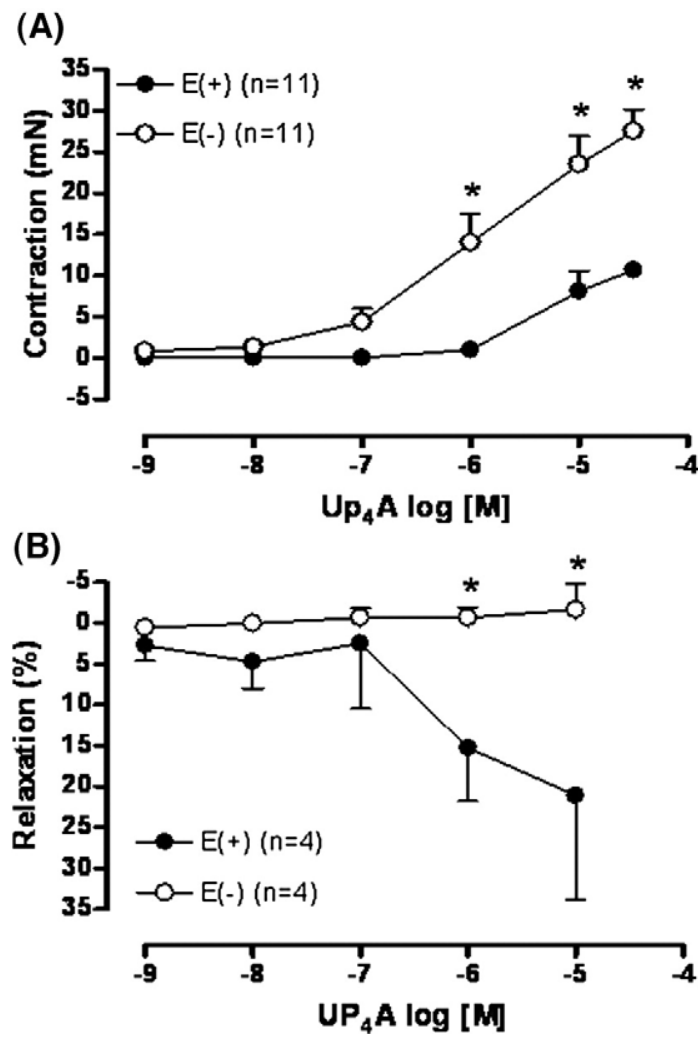

Fig. 1. $\mathrm{Up}_{4} \mathrm{~A}$ induces contraction and relaxation in rat aorta. Concentration-effect curves to $\mathrm{Up}_{4} \mathrm{~A}\left(10^{-9}\right.$ to $\left.3 \times 10^{-5} \mathrm{M}\right)$ were performed in endothelium-intact $[\mathrm{E}(+)]$ and endotheliumdenuded $[\mathrm{E}(-)]$ rat aortic rings. In $(\mathrm{A})$ the rings were treated from the baseline and in (B) the rings were contracted in response to phenylephrine $10^{-7} \mathrm{M}$. The points represent the mean \pm S.E.M. of the force displacement in $\mathrm{mN}$ (for contraction) or as $\%$ of relaxation of the contraction induced by phenylephrine $\left(10^{-7} \mathrm{M}\right)$. " $n$ " represents the number of animals. * represents $P$ value $<0.05$ compared to endothelium-denuded rat aortic rings. 


\section{Results}

3.1. Up 4 A-induced contraction of rat aortic rings is modulated by the endothelium

The ability of $\mathrm{Up}_{4} \mathrm{~A}\left(10^{-9}-3 \times 10^{-5} \mathrm{M}\right)$ to induce contraction was tested in $\mathrm{E}(+)$ and $\mathrm{E}(-)$ rat aortic rings. $\mathrm{Up}_{4} \mathrm{~A}$ caused contraction of rat aortic rings in a concentration-dependent manner, and the contraction was significantly potentiated by endothelium removal (Fig. 1A). The maximum contraction observed to the highest concentration of $\mathrm{Up}_{4} \mathrm{~A}\left(3 \times 10^{-5} \mathrm{M}\right)$ corresponded to approximately $30 \%$ and $80 \%$ of the contractile response induced by phenylephrine $\left(10^{-6} \mathrm{M}\right)$ in rat aortic rings with and without endothelium, respectively (data not shown).

\section{2. $U p_{4} A$-induced relaxation of rat aortic rings is endothelium dependent}

Endothelium-intact and denuded rat aortic rings were contracted with phenylephrine $\left(10^{-7} \mathrm{M}\right)$ followed by a cumulative concentration-effect curve induced by $\mathrm{Up}_{4} \mathrm{~A}\left(10^{-9}-10^{-5} \mathrm{M}\right)$. Up 4 A induced a modest relaxation $(\sim 25 \%)$ of the contraction to phenylephrine in endothelium-intact rat aortic rings. The absence of endothelium prevented $\mathrm{Up}_{4} \mathrm{~A}$-induced relaxation (Fig. 1B).

3.3. $\mathrm{Up}_{4} A$-induced contraction of rat aortic rings is modulated by $\mathrm{NO}$ pathway

The vasoconstriction induced by $\operatorname{Up}_{4} \mathrm{~A}\left(10^{-9}-3 \times 10^{-5} \mathrm{M}\right)$ was tested in endothelium-intact (Fig. 2A) and endothelium-denuded (Fig. 2B) rat aortic rings in the absence and in the presence of the non-selective NO

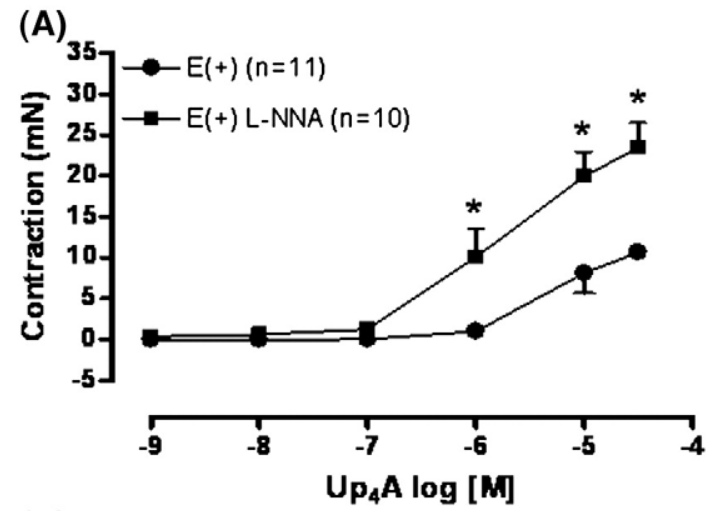

(B)

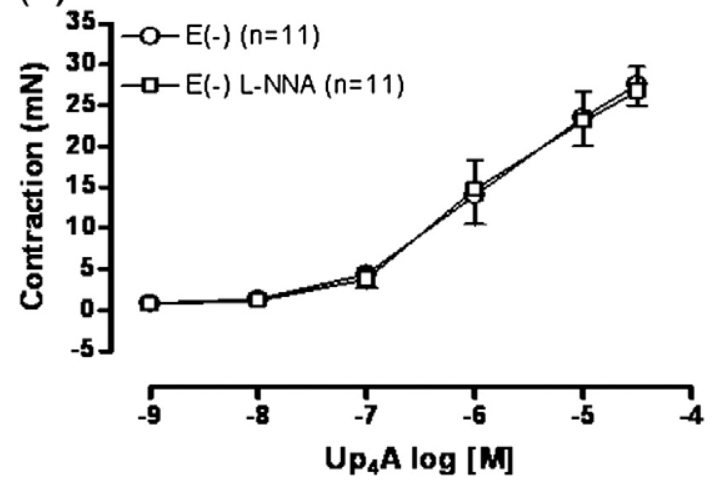

Fig. 2. $\mathrm{Up}_{4} \mathrm{~A}$-induced contraction is significantly potentiated by endothelium removal and NO synthase inhibition. Concentration-effect curves to $\mathrm{Up}_{4} \mathrm{~A}\left(10^{-9}\right.$ to $\left.3 \times 10^{-5} \mathrm{M}\right)$ were performed in $(A)$ endothelium-intact $[E(+)]$ and $(B)$ endothelium-denuded $[E(-)]$ rat aortic rings in the absence and in the presence of L-NNA $\left(10^{-4} \mathrm{M}\right)$ for $30 \mathrm{~min}$. The points represent the mean \pm S.E.M. of the force displacement in $\mathrm{mN}$, " $n$ " represents the number of animals and $*$ represents $P$ value $<0.05$ compared to the response obtained in the absence of L-NNA.

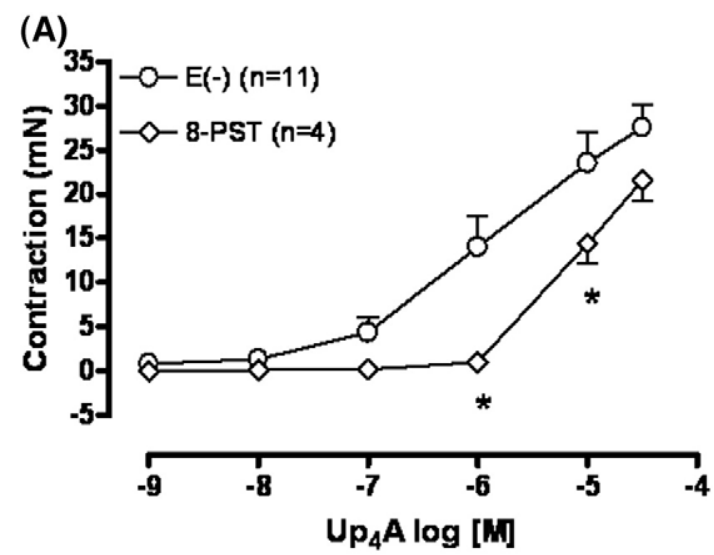

(B)

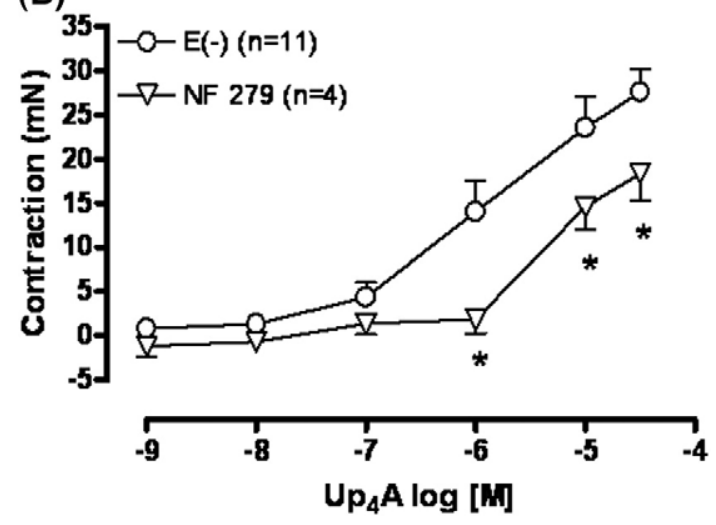

Fig. 3. $\mathrm{Up}_{4} \mathrm{~A}$-induced contraction involves activation of $\mathrm{P} 1$ and $\mathrm{P} 2 \mathrm{X} 1$ receptors. Concentration-effect curves to $\mathrm{Up}_{4} \mathrm{~A}\left(10^{-9}\right.$ to $\left.3 \times 10^{-5} \mathrm{M}\right)$ were performed in endothelium-denuded $[\mathrm{E}(-)]$ rat aortic rings in the absence and in the presence of (A) the non-selective antagonist of adenosine A1 and A2 receptors 8 -PST $\left(10^{-4} \mathrm{M}\right)$, and (B) the non-selective P2X1 receptor antagonist NF279 $\left(10^{-4} \mathrm{M}\right)$. The points represent the mean \pm S.E.M. of the force displacement in $\mathrm{mN}$, " $n$ " represents the number of animals and $*$ represents $P$ value $<0.05$ compared to the response obtained in the absence of the antagonist.

synthase inhibitor L-NNA $\left(10^{-4} \mathrm{M}\right)$ for $30 \mathrm{~min}$. Incubation with L-NNA did not affect the $\mathrm{Up}_{4} \mathrm{~A}$-induced contraction in $\mathrm{E}(-)$ rings (Fig. $2 \mathrm{~B}$ ), but significantly increased the contraction observed in $E(+)$ rings to a similar extent observed by endothelium removal (Fig. 2A compared to Fig. 1A).

3.4. Up 4 A-induced contraction is reversible and does not induce tachyphylaxis in rat aortic rings

Two consecutive curves to $\mathrm{Up}_{4} \mathrm{~A}$ were tested in aortic rings $\mathrm{E}(-)$ and $\mathrm{E}(+)$ treated with L-NNA. After the maximum response was obtained for the highest concentration of $\mathrm{Up}_{4} \mathrm{~A}$ on the first curve, the aortic rings were freed from the agonist through several wash out events. After a period of $60 \mathrm{~min}$ the rings returned to the baseline tension (approximately $30 \mathrm{mN}$ ). The second curve to $\mathrm{Up}_{4} \mathrm{~A}$ obtained after this restabilization period was similar to the first one obtained in both $\mathrm{E}(-)$ and $\mathrm{E}(+) / \mathrm{L}-\mathrm{NNA}$ (data not shown).

3.5. $P 1$ and $P 2 X$ receptors play an important role on $U p_{4} A$-induced contraction in endothelium-denuded rat aortic rings

To investigate the involvement of the $\mathrm{P} 1$ receptors in $\mathrm{Up}_{4} \mathrm{~A}$-induced contraction, we tested the ability of the P1 receptor antagonist 8-PST with known affinity for A1 and A2 receptors (Bruns, 1981; Bruns et al., 1986; Petrack et al., 1981) to inhibit endothelium-denuded aortic ring $\mathrm{Up}_{4} \mathrm{~A}$-induced contraction. Fig. $3 \mathrm{~A}$ demonstrates that the $\mathrm{P} 1$ receptor antagonist 8 -PST $\left(10^{-4} \mathrm{M}\right)$ significantly shifted $\mathrm{Up}_{4} \mathrm{~A}$-induced 
contraction in a parallel and competitive fashion suggesting the involvement of P1 receptors.

To study the contribution of the P2X receptors in $\mathrm{Up}_{4} \mathrm{~A}$-induced contraction, we tested the ability of the non-selective P2X receptor antagonist NF279 with known affinity for P2X1 and P2X3 receptors (Rettinger et al., 2000) to inhibit $\mathrm{Up}_{4} \mathrm{~A}$-induced contraction of endothelium-denuded aortic rings. NF279 $\left(10^{-4} \mathrm{M}\right)$ significantly rightward shifted the $\mathrm{Up}_{4} \mathrm{~A}$-induced contraction confirming the involvement of $\mathrm{P} 2 \mathrm{X}$ receptors (Fig. 3B).

3.6. Up ${ }_{4} A$-induced contraction in endothelium-denuded rat aortic rings involves L-type $\mathrm{Ca}^{2+}$ channels and Rho-kinase pathway

The vasoconstriction induced by $\mathrm{Up}_{4} \mathrm{~A}\left(10^{-9}-3 \times 10^{-5} \mathrm{M}\right)$ was tested in endothelium-denuded rat aortic rings in the absence and in the presence of the selective L-type $\mathrm{Ca}^{2+}$ channel blocker nifedipine or the Rho-kinase inhibitor Y-27632. After 30 min incubation with nifedipine $\left(10^{-5} \mathrm{M}\right) \mathrm{Up}_{4} \mathrm{~A}$-induced contraction was blunted (Fig. 4A), whereas incubation with $\mathrm{Y}-27632\left(10^{-7} \mathrm{M}\right)$ significantly reduced the contraction induced by $\mathrm{Up}_{4} \mathrm{~A}$ in endothelium-denuded aortic rings (Fig. 4B).

\section{7. $U p_{4} A$-induced contraction in endothelium-denuded rat aortic rings} involves superoxide anion formation

To investigate the involvement of superoxide anion to $\mathrm{Up}_{4} \mathrm{~A}$-induced contraction, we tested the ability of the superoxide dismutase mimetic/ superoxide anion scavenger tempol, or the NADPH oxidase inhibitor apocynin to inhibit $\mathrm{Up}_{4} \mathrm{~A}$-induced contraction of endothelium-denuded

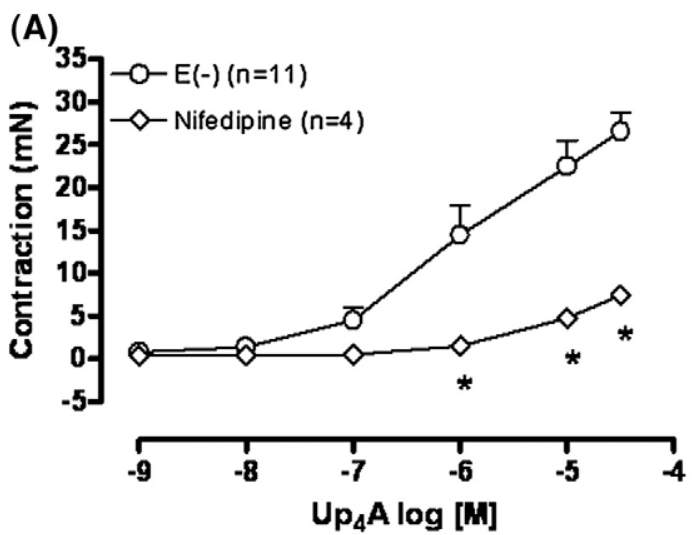

(B)

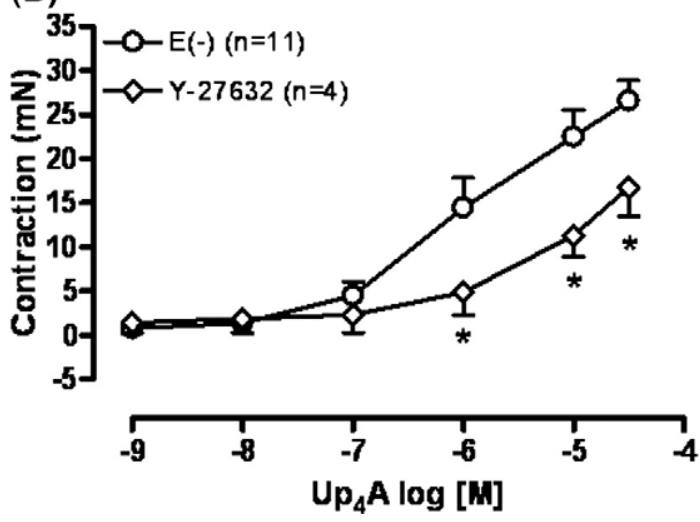

Fig. 4. $\mathrm{Up}_{4} \mathrm{~A}$-induced contraction involves activation of L-type $\mathrm{Ca}^{2+}$ channels and the Rho-kinase pathway. $\operatorname{CCEC}(\mathrm{s})$ to $\mathrm{Up}_{4} \mathrm{~A}\left(10^{-9}\right.$ to $\left.3 \times 10^{-5} \mathrm{M}\right)$ were performed in endothelium-denuded $[\mathrm{E}(-)]$ rat aortic ring in the absence and in the presence of (A) the selective L-type $\mathrm{Ca}^{2+}$ channel blocker nifedipine $\left(10^{-5} \mathrm{M}\right)$ or $(\mathrm{B})$ the selective Rho-kinase inhibitor Y-27632 $\left(10^{-7} \mathrm{M}\right)$. The points represent the mean \pm S.E.M. of the force displacement in $\mathrm{mN}$, " $n$ " represents the number of animals and * represents $P$ value $<0.05$ compared to the response obtained in the absence of the inhibitor.
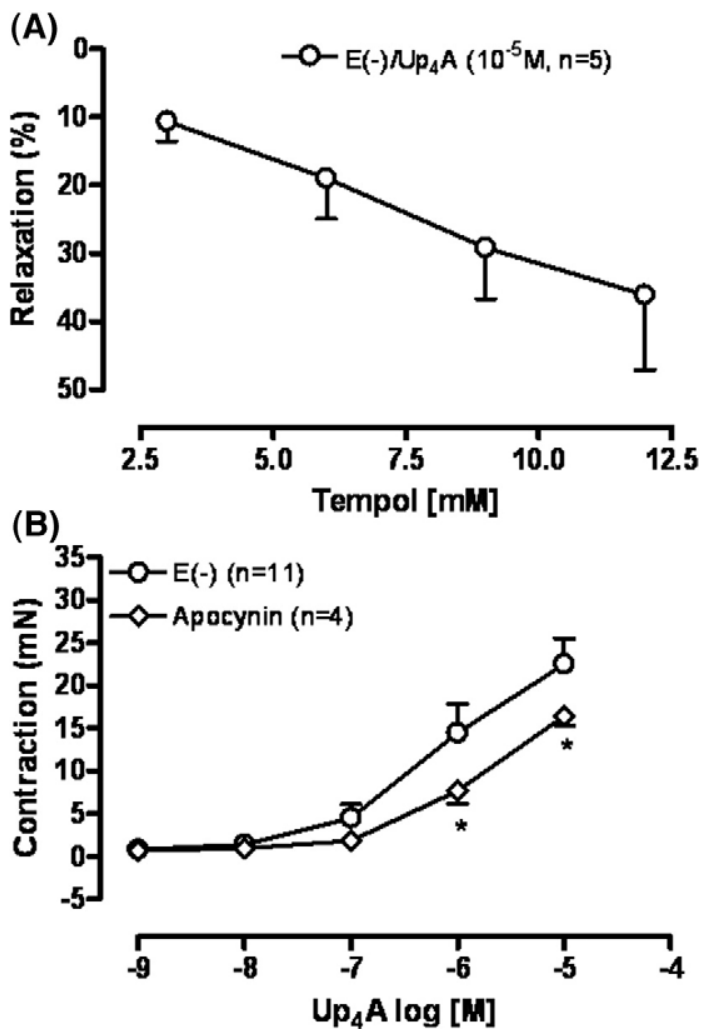

Fig. 5. $U \mathrm{p}_{4} \mathrm{~A}$-induced contraction involves superoxide anion formation. (A) Concentration-effect curve to the superoxide anion scavenger tempol (3-12 mM) was performed in endothelium-denuded $[\mathrm{E}(-)]$ rat aortic ring contracted with $\mathrm{Up}_{4} \mathrm{~A}\left(10^{-5} \mathrm{M}\right)$. (B) Concentration-effect curves to $\mathrm{Up}_{4} \mathrm{~A}\left(10^{-9}\right.$ to $\left.3 \times 10^{-5} \mathrm{M}\right)$ were constructed in endothelium-denuded $(E(-))$ rat aortic rings in the absence and in the presence of the selective NADPH oxidase inhibitor apocynin. The points represent the mean \pm S.E.M. of the force displacement in $\mathrm{mN}$ (for contraction) or as \% of relaxation of the contraction induced by $\mathrm{Up}_{4} \mathrm{~A}\left(10^{-5} \mathrm{M}\right)$. " $n$ " represents the number of animals. * represents $P$ value $<$ 0.05 compared to the response obtained in the absence of apocynin.

aortic rings. Fig. 5A demonstrates that contraction induced by $\mathrm{Up}_{4} \mathrm{~A}$ is inhibited $(\sim 35 \%)$ by tempol $(12 \mathrm{mM})$. The concentration-effect curve induced by $\mathrm{Up}_{4} \mathrm{~A}$ is significantly shifted to the right in the presence of apocynin $\left(10^{-4} \mathrm{M}\right)$ (Fig. 5B).

\section{Discussion}

We present here the unique findings that the novel endotheliumderived factor $\mathrm{Up}_{4} \mathrm{~A}$, originally described as a vasoconstrictor (Jankowski et al., 2005), also causes endothelium-dependent relaxation of rat aortic rings.

Adenine and uracil nucleotides contribute to the local regulation of vascular tone (Olsson and Pearson, 1990; Ralevic and Burnstock, 1991). Dinucleotides have also been shown to control vascular tone (Jankowski et al., 2003; Jankowski et al., 2005; Tolle et al., 2006). However, dinucleotides containing two purines as moieties are the most common naturally-occurring signaling molecules. $\mathrm{Up}_{4} \mathrm{~A}$ is the first dinucleotide containing one purine and one pyrimidine moiety found in living organisms (Jankowski et al., 2005). The potency and type of response of the dinucleotides are largely determined by the number of phosphates in the polyphosphate chain (Lewis et al., 1994; Lewis et al., 2000; Ralevic et al., 1995; Ralevic et al., 2001). In general, dinucleotides containing a phosphate chain of 2-3 compounds elicit vasorelaxation, whereas those containing a longer chain of 4 to 6 elicit vasoconstriction followed by vasodilation. Despite the characterization of $\mathrm{Up}_{4} \mathrm{~A}$ as a potent vasoconstrictor of isolated perfused rat kidney, little is known about its properties in other vascular tissues. Furthermore, the ability of $\mathrm{Up}_{4} \mathrm{~A}$ to induce relaxations has not been previously reported. 
Two major families of purinoceptors, named P1 and P2 have been described. P1 and P2 receptor activation can cause both vasoconstriction and vasodilatation in the cardiovascular system. The responses induced by purines and pyrimidines varies extensively according to the tissue and specie studied. All P1 receptors are metabotropic (Gcoupled protein) and specific agonists and antagonists are available for each different subtype (Burnstock, 2004). On the other hand, the lack of selective agonists and antagonists for P2 receptors has impeded a more detailed pharmacological characterization of the $\mathrm{P} 2$ receptors involved in the control of vascular tone.

We observed that $\mathrm{Up}_{4} \mathrm{~A}$ induced a modest endothelium-dependent relaxation of rat aortic rings contracted with phenylephrine. The current literature would support the view that endothelium-dependent relaxation of rat aorta mediated by P1 receptors may involve the A2A (Lewis et al., 1994) and A2B (Prentice and Hourani, 1996). P2-mediated endothelium-dependent rat aorta relaxation involves P2Y1- and P2Y2like receptors (Hansmann et al., 1997). Rat vascular endothelial cells express P2Y receptors that mediate relaxation via the nitric oxide pathway. In murine aorta, in addition to P2Y1 and P2Y2, P2Y6 is also involved in the relaxing responses (Guns et al., 2005). Further studies are necessary to characterize the receptor subtype in endothelium-dependent relaxation induced by Up4A in rat aorta.

$\mathrm{Up}_{4} \mathrm{~A}$-induced contraction of rat aorta was significantly increased by endothelium removal or by nitric oxide synthase inhibition. Jankowski et al. (2005) also observed that the vasoconstrictor effect of $\mathrm{Up}_{4} \mathrm{~A}$ in perfused isolated kidney is increased after blockade of nitric oxide synthase (Jankowski et al., 2005). The contraction induced by certain guanine and by adenine nucleotides is modulated by the endothelium in rat aorta (Bultmann et al., 1997; Shen et al., 2000). In chorionic vessels, adenosine-induced contraction is also modulated by the endothelium (Donoso et al., 2005). Endothelium modulation of contractile responses elicited by agonists is an extensively reported phenomenon and, therefore, is not surprising to occur for $\mathrm{Up}_{4} \mathrm{~A}$.

In addition to characterizing the contractile and relaxing actions of $\mathrm{Up}_{4} \mathrm{~A}$ in rat aorta, we tentatively identified the receptor subtypes and their intracellular signaling mechanisms. The contraction induced by $\mathrm{Up}_{4} \mathrm{~A}$ in endothelium-denuded rat aortic rings was significantly inhibited by the non-selective P2X1/P2X3 receptor antagonist NF 279. Vascular smooth muscle cells express multiple P2X and P2Yreceptors that cause contraction. P2X1 is the primary subtype expressed on vascular smooth muscle involved in vasoconstriction. In rat aortic smooth muscle cells, the presence of P2X1, P2X2, P2X4, P2Y2 and P2Y6 has been shown [for review: (Kunapuli and Daniel, 1998)]. In addition, a study reported that purine dinucleotides containing 4 to 6 phosphates in the polyphosphate chain cause contraction mediated by P2X1 receptor present on the smooth muscle (Lewis et al., 2000). Based on these data, our results indicate that dinucleotides containing both purine and pyrimidine moieties and a long polyphosphate chain induce contraction by partially activating P2X1 receptors on the smooth muscle.

Interestingly, the non-selective P1 receptor antagonist 8-PST also inhibited $\mathrm{Up}_{4} \mathrm{~A}$-induced contraction. Adenosine is the prototype agonist for P1 receptors. P1 receptor activation is generally associated with vasodilation (Liu et al., 2002). For many years it was accepted that adenosine evoked dilatation by stimulation of $\mathrm{A} 2$ receptors (particularly A2A subtype) on the vascular smooth muscle via an increase in cAMP (Olsson and Pearson, 1990). In the kidney, adenosine produces vasoconstriction and vasodilatation through activation of A1 and A2, respectively (Inscho, 2003). Exceptionally, in aorta from hypertensive rats, P1 receptor activation has been shown to mediate endotheliumdependent contraction (Fahim and Mustafa, 2001; Tawfik et al., 2005). In addition, in human chorionic vessels, A2B adenosine receptor mediates contraction (Donoso et al., 2005). There have been some reports that diadenosine tetraphosphate $\left(\mathrm{Ap}_{4} \mathrm{~A}\right)$ contractile response in rat urinary bladder is mediated by P1-purinoceptor whereas ATP responses were not affected by the P1 receptor antagonist theophyline (Khattab et al.,
2002; Khattab and Al-Hrasen, 2006). To our knowledge, this is the first report showing the involvement of P1 receptor in vascular smooth muscle mediating contraction in aorta from normotensive rats.

The calcium channel blocker nifedipine inhibited the contraction induced by $U_{4} A$ in endothelium-denuded rat aortic rings. In rat aorta, nifedipine has been reported ineffective to inhibit the contraction or increase in intracellular calcium concentration induced by P2 receptors activation (Kalthof et al., 1993; Shen et al., 2000). On the other hand, nifedipine inhibits the contraction induced by adenosine in afferent arterioles and by $\mathrm{Ap}_{4} \mathrm{~A}$ and ATP in rat urinary bladder (Hansen et al., 2007; Khattab et al., 2002). These data support the presence of a P1 receptor in the smooth muscle of rat aorta mediating contraction, dependent on extracellular calcium influx.

The Rho-kinase inhibitor Y27632 (Uehata et al., 1997) inhibited $\mathrm{Up}_{4} \mathrm{~A}$-induced contraction of endothelium-denuded rat aortic rings. In rat aorta, nucleotides can induce contraction mediated by P2X, P2Y2 and P2Y6 receptor activation (Bultmann et al., 1997). Furthermore, P2Y1, P2Y2, P2Y4 and P2Y6 receptors have been shown to be coupled to Rhokinase activation in rat aortic smooth muscle cells (Sauzeau et al., 2000). Based on this information, our results suggest the possible involvement of $\mathrm{P} 2 \mathrm{Y}$ receptors in the contraction induced by $\mathrm{Up}_{4} \mathrm{~A}$ in rat aorta.

Our data demonstrate that the membrane permeable reactive oxygen species scavenger tempol, and the NADPH oxidase inhibitor apocynin significantly reduced $\mathrm{Up}_{4} \mathrm{~A}$-induced contraction in rat aorta suggesting an important role for superoxide anion formation. To our knowledge, there have been no reports on superoxide formation after purinergic receptor activation in the vasculature. However, it has been reported that $\mathrm{Ap}_{4} \mathrm{~A}$ as well as ATP-induced contractile responses in rat urinary bladder involves superoxide formation (Khattab et al., 2002; Khattab and Al-Hrasen, 2006). Furthermore, activation of ATP receptors causes increase in $\mathrm{Ca}^{+2}$ transients and production of superoxide anion in human eosinophil granulocytes, human prostate tumor spheroids and human tumor thyroid cell line (Dichmann et al., 2000; Pines et al., 2005; Sauer et al., 2001).

Tachyphylaxis, characterized by a rapidly decreasing response to a pharmacologically active agent after its initial administration, is a phenomenon that has been observed for many vasoconstrictor agents such as angiotensin II (Holloway et al., 2002; Linder et al., 2007; Thomas, 1999), endothelin 1 (Linder and Bendhack, 2002), serotonin (De Mey and Vanhoutte, 1981) and ATP (Shen et al., 2000). It has also been reported that ATP and diadenosine tetraphosphate $\left(\mathrm{Ap}_{4} \mathrm{~A}\right)$ exhibit significant tachyphylaxis in isolated rat urinary bladder (Khattab et al., 2002; Shen et al., 2000). The fact that $\mathrm{Up}_{4} \mathrm{~A}$ exhibits no tachyphylactic pattern indicates that the $\mathrm{Up}_{4} \mathrm{~A}$-induced constriction of rat aortic rings cannot be explained by the presence of one of its degradation products. These data confirm the findings that ATP or UTP do not contribute to the $\mathrm{UP}_{4} \mathrm{~A}$-induced contraction observed previously in isolated perfused rat kidney (Jankowski et al., 2005).

A number of cardiovascular diseases involve alterations in the synthesis of vasoactive compounds. Hypertension is associated with increased vasoconstriction and decreased relaxation usually accompanied by endothelium dysfunction. It has been recently reported that the plasma of juvenile hypertensive subjects presents increased levels of $U_{4} A$ (Jankowski et al., 2007). The results of the present study indicate that the endogenous compound $\mathrm{Up}_{4} \mathrm{~A}$ may be involved in the control of vascular tone and, therefore, may have a strong impact in cardiovascular diseases. Understanding the pharmacological and physiological function and regulation of vascular tone by $U_{4} \mathrm{~A}$ may be of extreme value to understanding the pathophysiology and treatment of these diseases.

\section{Acknowledgements}

This work was supported by the National Institute of Health (HL74167). Dr. AE Linder is a recipient of an American Heart Association Postdoctoral Fellowship. 


\section{References}

Boarder, M.R., Hourani, S.M., 1998. The regulation of vascular function by P2 receptors: multiple sites and multiple receptors. Trends Pharmacol. Sci. 19, 99.

Bruns, R.F., 1981. Adenosine antagonism by purines, pteridines and benzopteridines in human fibroblasts. Biochem. Pharmacol. 30, 325.

Bruns, R.F., Lu, G.H., Pugsley, T.A., 1986. Characterization of the A2 adenosine receptor labeled by [3H]NECA in rat striatal membranes. Mol. Pharmacol. 29, 331.

Bultmann, R., Hansmann, G., Tuluc, F., Starke, K., 1997. Vasoconstrictor and vasodilator effects of guanine nucleotides in the rat aorta. Naunyn Schmiedeberg's Arch. Pharmacol 356, 653.

Burnstock, G., 2004. Introduction: P2 receptors. Curr. Top. Med. Chem. 4, 793.

Buvinic, S., Poblete, M.I., Donoso, M.V., Delpiano, A.M., Briones, R., Miranda, R., HuidobroToro, J.P., 2006. P2Y1 and P2Y2 receptor distribution varies along the human placental vascular tree: role of nucleotides in vascular tone regulation. J. Physiol. 573, 427.

Communi, D., Janssens, R., Suarez-Huerta, N., Robaye, B., Boeynaems, J.M., 2000 Advances in signalling by extracellular nucleotides. the role and transduction mechanisms of P2Y receptors. Cell. Signal. 12, 351.

Dalziel, H.H., Westfall, D.P., 1994. Receptors for adenine nucleotides and nucleosides: subclassification, distribution, and molecular characterization. Pharmacol. Rev. $46,449$.

De Mey, C., Vanhoutte, P.M., 1981. Effect of age and spontaneous hypertension on the tachyphylaxis to 5-hydroxytryptamine and angiotensin II in the isolated rat kidney. Hypertension 3, 718.

Dichmann, S., Idzko, M., Zimpfer, U., Hofmann, C., Ferrari, D., Luttmann, W., Virchow Jr., C., Di Virgilio, F., Norgauer, J., 2000. Adenosine triphosphate-induced oxygen radical production and $\mathrm{CD} 11 \mathrm{~b}$ up-regulation: $\mathrm{Ca}(++)$ mobilization and actin reorganization in human eosinophils. Blood 95, 973.

Donoso, M.V., Lopez, R., Miranda, R., Briones, R., Huidobro-Toro, J.P., 2005. A2B adenosine receptor mediates human chorionic vasoconstriction and signals through arachidonic acid cascade. Am. J. Physiol. Heart Circ. Physiol. 288, H2439.

Fahim, M., Mustafa, S.J., 2001. Evidence for the presence of A(1) adenosine receptors in the aorta of spontaneously hypertensive rats. Br .J. Pharmacol. 134, 1760.

Fredholm, B.B., Abbracchio, M.P., Burnstock, G., Daly, J.W., Harden, T.K., Jacobson, K.A. Leff, P., Williams, M., 1994. Nomenclature and classification of purinoceptors. Pharmacol. Rev. 46, 143.

Guns, P.J., Korda, A., Crauwels, H.M., Van Assche, T., Robaye, B., Boeynaems, J.M., Bult, H. 2005. Pharmacological characterization of nucleotide P2Y receptors on endothelial cells of the mouse aorta. Br. J. Pharmacol. 146, 288.

Hansen, P.B., Friis, U.G., Uhrenholt, T.R., Briggs, J., Schnermann, J., 2007. Intracellular signalling pathways in the vasoconstrictor response of mouse afferent arterioles to adenosine. Acta Physiol. (Oxf) 191, 89.

Hansmann, G., Bultmann, R., Tuluc, F., Starke, K., 1997. Characterization by antagonists of P2-receptors mediating endothelium-dependent relaxation in the rat aorta. Naunyn Schmiedeberg's Arch. Pharmacol. 356, 641.

Holloway, A.C., Qian, H., Pipolo, L., Ziogas, J., Miura, S., Karnik, S., Southwell, B.R., Lew, M.J., Thomas, W.G., 2002. Side-chain substitutions within angiotensin II reveal different requirements for signaling, internalization, and phosphorylation of type $1 \mathrm{~A}$ angiotensin receptors. Mol. Pharmacol. 61, 768.

Inscho, E.W., 2003. Modulation of renal microvascular function by adenosine. Am. J. Physiol. Regul. Integr. Comp. Physiol. 285, R23.

Inscho, E.W., Cook, A.K., 2002. P2 receptor-mediated afferent arteriolar vasoconstriction during calcium blockade. Am. J. Physiol. Renal. Physiol. 282, F245.

Jankowski, J., Jankowski, V., Seibt, B., Henning, L., Zidek, W., Schluter, H., 2003. Identification of dinucleoside polyphosphates in adrenal glands. Biochem. Biophys. Res. Commun. 304, 365.

Jankowski, V., Meyer, A.A., Schlattmann, P., Gui, Y., Zheng, X.L., Stamcou, I., Radtke, K. Tran, T.N., van der Giet, M., Tolle, M., Zidek, W., Jankowski, J., 2007. Increased uridine adenosine tetraphosphate concentrations in plasma of juvenile hypertensives. Arterioscler. Thromb. Vasc. Biol. 27, 1776

Jankowski, V., Tolle, M., Vanholder, R., Schonfelder, G., van der Giet, M., Henning, L., Schluter, H., Paul, M., Zidek, W., Jankowski, J., 2005. Uridine adenosine tetraphosphate: a novel endothelium-derived vasoconstrictive factor. Nat. Med. 11, 223.

Kalthof, B., Bechem, M., Flocke, K., Pott, L., Schramm, M., 1993. Kinetics of ATP-induced $\mathrm{Ca} 2+$ transients in cultured pig aortic smooth muscle cells depend on ATP concentration and stored Ca2+. J. Physiol. 466, 245.

Khattab, M., A.L.-S. O, E.L.-K. H, 2002. Comparative study of the contractile activity evoked by ATP and diadenosine tetraphosphate in isolated rat urinary bladder Pharmacol. Res. 45, 93.
Khattab, M.M., Al-Hrasen, M.N., 2006. Contractile activity of ATP and diadenosine tetraphosphate on urinary bladder in the rats: role of superoxide anion and urothelium. Auton. Autacoid Pharmacol. 26, 149

Knight, G.E., Burnstock, G., 2001. Identification of P1 and P2 purinoceptors in the aorta of the lizard (Agama sp.). Comp. Biochem. Physiol. C Toxicol. Pharmacol. $128,413$.

Kunapuli, S.P., Daniel, J.L., 1998. P2 receptor subtypes in the cardiovascular system. Biochem. J. 336 (Pt 3), 513.

Lewis, C.D., Hourani, S.M., Long, C.J., Collis, M.G., 1994. Characterization of adenosine receptors in the rat isolated aorta. Gen. Pharmacol. 25, 1381.

Lewis, C.J., Gitterman, D.P., Schluter, H., Evans, R.J., 2000. Effects of diadenosine polyphosphates $(\mathrm{Ap}(\mathrm{n}) \mathrm{As})$ and adenosine polyphospho guanosines $(\mathrm{Ap}(\mathrm{n}) \mathrm{Gs})$ on rat mesenteric artery P2X receptor ion channels. Br. J. Pharmacol. 129, 124.

Linder, A.E., Bendhack, L.M., 2002. Endothelin-1-induced contraction is impaired in the tail artery of renal hypertensive rats. Vascul. Pharmacol. 39, 77.

Linder, A.E., Thakali, K.M., Thompson, J.M., Watts, S.W., Webb, R.C., Leite, R., 2007. Methyl-beta-cyclodextrin prevents angiotensin II-induced tachyphylactic contractile responses in rat aorta. J. Pharmacol. Exp. Ther. 323, 78.

Liu, S.H., Shan, L.M., Wang, H., 2002. Pharmacological characteristics of novel putative purinoceptors in vascular endothelium. Cell Biol. Intl. 26 (11), 963.

Malec, D., 1996. Purinergic receptors. Pol. J. Pharmacol. 48, 457.

North, R.A., 2002. Molecular physiology of P2X receptors. Physiol. Rev. 82, 1013.

Olsson, R.A., Pearson, J.D., 1990. Cardiovascular purinoceptors. Physiol. Rev. 70, 761

Petrack, B., Czernik, A.J., Ansell, J., Cassidy, J., 1981. Potentiation of arginine-induced glucagon secretion by adenosine. Life Sci. 28, 2611.

Pines, A., Perrone, L., Bivi, N., Romanello, M., Damante, G., Gulisano, M., Kelley, M.R., Quadrifoglio, F., Tell, G., 2005. Activation of APE1/Ref-1 is dependent on reactive oxygen species generated after purinergic receptor stimulation by ATP. Nucleic Acids Res. 33, 4379.

Prentice, D.J., Hourani, S.M., 1996. Activation of multiple sites by adenosine analogues in the rat isolated aorta. Br. J. Pharmacol. 118, 1509.

Ralevic, V., Burnstock, G., 1991. Roles of P2-purinoceptors in the cardiovascular system. Circulation 84, 1

Ralevic, V., Burnstock, G., 1998. Receptors for purines and pyrimidines. Pharmacol. Rev. $50,413$.

Ralevic, V., Hoyle, C.H., Burnstock, G., 1995. Pivotal role of phosphate chain length in vasoconstrictor versus vasodilator actions of adenine dinucleotides in rat mesenteric arteries. J. Physiol. 483 (Pt 3), 703.

Ralevic, V., Jankowski, J., Schluter, H., 2001. Structure-activity relationships of diadenosine polyphosphates $(\mathrm{Ap}(\mathrm{n}) \mathrm{As})$, adenosine polyphospho guanosines $(\mathrm{Ap}(\mathrm{n}) \mathrm{Gs})$ and guanosine polyphospho guanosines $(\mathrm{Gp}(\mathrm{n}) \mathrm{Gs})$ at $\mathrm{P} 2$ receptors in the rat mesenteric arterial bed. Br. J. Pharmacol. 134, 1073.

Rettinger, J., Schmalzing, G., Damer, S., Muller, G., Nickel, P., Lambrecht, G., 2000. The suramin analogue NF279 is a novel and potent antagonist selective for the P2X(1) receptor. Neuropharmacology 39, 2044.

Sauer, H., Klimm, B., Hescheler, J., Wartenberg, M., 2001. Activation of p90RSK and growth stimulation of multicellular tumor spheroids are dependent on reactive oxygen species generated after purinergic receptor stimulation by ATP. Faseb J. 15, 2539.

Sauzeau, V., Le Jeune, H., Cario-Toumaniantz, C., Vaillant, N., Gadeau, A.P., Desgranges, C., Scalbert, E., Chardin, P., Pacaud, P., Loirand, G., 2000. P2Y(1), P2Y(2), P2Y(4), and P2Y (6) receptors are coupled to Rho and Rho kinase activation in vascular myocytes. Am. J. Physiol. Heart Circ. Physiol. 278, H1751.

Shen, J.Z., Zheng, X.F., Kwan, C.Y., 2000. Evidence for P(2)-purinoceptors contribution in H (2) $\mathrm{O}(2)$-induced contraction of rat aorta in the absence of endothelium. Cardiovasc. Res. 47, 574.

Tawfik, H.E., Schnermann, J., Oldenburg, P.J., Mustafa, S.J., 2005. Role of A1 adenosine receptors in regulation of vascular tone. Am. J. Physiol. Heart Circ. Physiol. 288, H1411.

Thomas, W.G., 1999. Regulation of angiotensin II type 1 (AT1) receptor function. Regul. Pept. 79, 9

Tolle, M., Giebing, G., Tietge, U.J., Jankowski, J., Jankowski, V., Henning, L., Horl, M.P., Weiss, W., Zidek, W., van der Giet, M., 2006. Diguanosine pentaphosphate: an endogenous activator of Rho-kinase possibly involved in blood pressure regulation. J. Hypertens. $24,1991$.

Uehata, M., Ishizaki, T., Satoh, H., Ono, T., Kawahara, T., Morishita, T., Tamakawa, H., Yamagami, K., Inui, J., Maekawa, M., Narumiya, S., 1997. Calcium sensitization of smooth muscle mediated by a Rho-associated protein kinase in hypertension. Nature 389,990 . 